\title{
Cognitive decline affects diabetic women
}

\author{
Adam Perzyński ${ }^{1} \mathrm{~A}, \mathrm{C}-\mathrm{F}$, Iwona Chmiel-Perzyńska ${ }^{2} \mathrm{~A}-\mathrm{F}$,
}

\section{II Department of Psychiatry and Psychiatry Rehabilitation, Medical University in Lublin;} Ceramiczna 1, 20-150 Lublin, Poland

2. Department of Experimental and Clinical Pharmacology, Medical University in Lublin; Głuska 2, 20-439 Lublin, Poland

\begin{abstract}
Introduction: DM provokes peripheral complications and changes in central nervous system. Central changes in the course of diabetes mellitus (DM) include changes in brain tissue structure, electrophysiological abnormalities but also disturbances in neurotransmission leading to cognitive decline.

Aim of the study: The aim of our study was to asses cognitive functioning of patients suffering from DM1 for at least 5 years but without any diagnosed complications.

Materials and methods: Cognitive functions were assessed in 59 patients (35 men) with Trail Making Test A (TMT A) and B (TMT B), Maze Test (MT), Stroop Test (SCWT) and Rey Auditory Verbal Learning Test (RAVLT). Mental disorders were excluded with Beck's Depression Inventory (BT), Mini Mental State Examination (MMSE) and psychiatric examination.

Results: We stated that women, compared with men, presented worsening of executive functions, speed and motor control. Cognitive decline depended on number of episodes of at least moderate hypoglycemia and duration of disease. HbA1c below $8 \%$ resulted in better memory, speed and motor control. Cognitive decline was more escalated in the patients with atherogenic lipid profile.

Conclusions: It seems that even apparent lack of complications is not unambiguous with lack of cognitive decline and women seem to be more susceptible. DM1 affects young individuals, whose cognitive functions are in the course of the development, so it is important to find the underlying mechanisms and the areas of disturbed cognitive functioning and further investigations are needed.
\end{abstract}

Keywords: diabetes mellitus type 1, cognitive decline, hypoglycemia

\section{Streszczenie}

Wstęp: Cukrzyca wywołuje powikłania w obwodowym i ośrodkowym układzie nerwowym. Zmiany ośrodkowe dotyczą struktury tkanki mózgowej, nieprawidłowości elektrofizjologicznych oraz zaburzeń w neurotransmisji, co prowadzi do zaburzeń poznawczych.

Cel badania: Celem badania była ocena funkcji poznawczych u pacjentów chorujących na typ pierwszy cukrzycy od co najmniej 5 lat, u których nie stwierdzono obecności powikłań chorobowych.

Materiał i metody: Wybrane funkcje poznawcze oceniono u 59 pacjentów (35 mężczyzn) za pomocą Testu Łączenia Punktów A (TMT A) i B (TMT B), Test Labiryntu (MT), Testu Stroopa (SCWT) i Testu Pamięci Słuchowej Reya (RAVLT). Obecność zaburzeń psychicznych wykluczono stosując Skalę Depresji Beck’a (BT), Mini Mental State Examination oraz przeprowadzając badanie psychiatryczne.

Wyniki: Ustalono, że kobiety, w porównaniu z mężczyznami, prezentowały pogorszenie funkcji wykonawczych, prędkości i kontroli motorycznej. Sprawność kognitywna zależała od liczby co najmniej umiarkowanej hipoglikemii i czasu trwania choroby. Poziom hemoglobiny glikowanej (HbA1c) poniżej 8\% wiązał się z lepszą pamięcią, prędkością i sprawnością motoryczną. Deficyty poznawcze były bardziej nasilone u pacjentów z aterogenicznym profilem lipidowym.

Wnioski: Wydaję się, że nawet brak jawnych powikłań nie jest jednoznaczny z brakiem zaburzeń kognitywnych, na które kobiety zdają się być bardziej podatne. Cukrzyca typu pierwszego rozwija się u osób młodych, u których funkcje poznawcze są na etapie rozwoju, dlatego wyjaśnienie mechanizmów i obszarów zaburzeń kognitywnych jest istotne i wymaga dalszych badań.

Słowa kluczowe: cukrzyca typ 1, zaburzenia poznawcze, hipoglikemia

\section{Introduction}

Central changes in the course of diabetes mellitus (DM), both type 1 and 2, include changes in brain tissue structure, electrophysiological abnormalities but also disturbances in neurotransmission which were proved in experimental and clinical trials [1,2,3]. All those irregularities can lead to the loss of cognitive abilities, especially caused by DM complications and extreme high or low glucose levels $[1,4,5]$. There are only a few investigations concerning patients suffering from DM1 without distinct complications [6,7].

The aim of our study was to asses cognitive functioning of patients suffering from DM1 for at least 5 years but without diagnosed complications. 


\section{Materials and methods Patients}

Including criteria were at least 5 years duration of DM1, intensive insulin-therapy treatment, no diagnosed complications of DM1. Excluding criteria were psychic disturbances, mental retardation, poor controlled hypertension, coronary heart disease, history of stroke or myocardial infarction, nephropathy, retinopathy, other acute diseases or significant deviations in laboratory tests. Experimental procedures have been approved by the Local Ethical Committee in Lublin. We examined 24 women and 35 men. Mean duration of DM 1 was $12.8 \pm 4.3$ years. Mean age of patients was $32.5 \pm 7.4$ years.

\section{Experimental procedure Blood samples}

Blood samples were taken between 8 and 9 a.m., after at least 8 hours fasting and night resting. Hypoglycemia occurring at the night before examination excluded patient from the study. After physical examination blood glucose level was checked once again. All psychological tests were performed after breakfast and insulin injection in comfortable conditions and desirable glucose level was maintained above $100 \mathrm{mg} / \mathrm{dl}$.

\section{Cognitive function evaluation}

Cognitive functions were evaluated with Trail Making Test A (TMT A) and B (TMT B), Maze Test (MT), Stroop Test (SCWT) and Rey Auditory Verbal Learning Test (RAVLT). Mental disorders were excluded with Beck's Depression Inventory (BT), Mini Mental State Examination (MMSE) and clinical assessment.

SCWT investigates executive functioning, attention deployment, cognitive flexibility and selective attention $[5,8]$. TMT B investigates executive functions similarly to SCWT. Both TMT A and MT asses speed and motor control. RAVLT measuring memory, bases on memorizing string of words [5,8]. BT is widely used to diagnose depression. MMSE is used to evaluate global cognitive function and to asseses stage of dementia [5]. Statistical analysis was performed using Statistica 8.0.

\section{Results}

Mean results of laboratory tests are shown in table I.

Table I. Mean results of laboratory tests in examined group

\begin{tabular}{|l|c|}
\hline Parameter & $\begin{array}{c}\text { Mean value } \pm \text { Standard } \\
\text { Deviation }\end{array}$ \\
\hline HbA1c $(\%)$ & $8.45 \pm 1.34$ \\
\hline Glucose $(\mathrm{mg} / \mathrm{dl})$ & $204.9 \pm 89.1$ \\
\hline Total cholesterol $(\mathrm{mg} / \mathrm{dl})$ & $206.09 \pm 37.36$ \\
\hline HDL cholesterol $(\mathrm{mg} / \mathrm{dl})$ & $68.21 \pm 17.12$ \\
\hline LDL cholesterol $(\mathrm{mg} / \mathrm{dl})$ & $119.02 \pm 37.23$ \\
\hline Triglycerides $(\mathrm{mg} / \mathrm{dl})$ & $85.45 \pm 49.93$ \\
\hline Creatinine & $0.99 \pm 0.11$ \\
\hline Urea & $28.16 \pm 6.75$ \\
\hline
\end{tabular}

Women obtained better results in TMT B $(\mathrm{p}<0.01)$ and SCWT $(\mathrm{p}<0.01)$. Duration of disease influenced unfavorably the results of SCWT but only in the group of women $(p<0.05)$. Together with increased number of episodes of moderate and severe hypoglycemia patients needed more time in MT $(\mathrm{p}<0.05)$. This dependence was especially significant in the group of women $(\mathrm{p}<0.01)$. Number of episodes of hypoglycemia in women but not in men also worsened results in TMT A and TMT B (both $\mathrm{p}<0.05$ ).

There were no differences in performed tests between groups $\mathrm{HbA} 1 \mathrm{c}<8$ and $>8 \%$ but in group with higher level of HbA1c negative correlations with results in MT $(\mathrm{p}<0.01)$ and positive with RAVLT $(\mathrm{p}<0.05)$ were proved. Interestingly, we also found positive correlation of results in RAVLT and glucose level during examination $(\mathrm{p}<0.01)$ and this effect was present in the group of women but not men. On the other hand blood glucose level below $200 \mathrm{mg} / \mathrm{dl}$ may improve results only in SCWT $(p=0.05)$. Disadvantageous influence on RAVLT results of total cholesterol ( $p<0.05)$, LDL cholesterol $(p<0.01)$ and triglycerides $(p>0.05)$ and advantageous influence of HDL cholesterol $(p<0.05)$ were observed. Total cholesterol level above $200 \mathrm{mg} / \mathrm{dl}$ deteriorated results in TMT B $(\mathrm{p}<0.001)$ and SCWT $(\mathrm{p}<0.05)$. Elevated LDL cholesterol also worsen results in SCWT $(\mathrm{p}<0.05)$.

\section{Discussion}

Obtained results suggest that DM1 can affect different domains of cognitive functioning. Because better results of women in some tests, especially SCWT are described in literature, our results are especially distressing. It seems that particularly women are prone to hypoglycemia, which worsens executive functions, speed and motor control. Moreover in women worse glucose control disturbed cognitive functioning at the time of examination congruently with worse long time scores. Obtained results suggest that slight increase of total cholesterol, LDL cholesterol and triglyceride level disturb executive functions and reduced LDL level promotes speed and motor control and this relationship is not sex-dependent.

The relationship between sex and deterioration of frontal lobe function dependent on low glucose level is not unambiguous. Because no gender-related changes were reported, probably other than low glucose level, not defined factors can be significant. Our observation that time of duration of DM 1 can also lead to cognitive decline is confirmed in other investigations [7]. Poor glucose control and episodes of hypoglycemia also seem to be crucial. They are patient-dependent factors leading to cognitive decline [9]. Available data suggest that especially type of DM but also presence of nephropathy or retinopathy should be considered [4,5]. However, in our group, no symptoms of angiopathy were diagnosed so other factors should be important. In different investiga- 
tions, cholesterol level was rather analyzed as a risk factor of atherogenesis but not the only factor leading to depletion of cognitive functions. It is known that treatment with statins does not improve results in neuropsychological tests despite of favorable effect on cholesterol fraction concentration and anti-inflammatory effect [10]. Moreover, many investigations concerned elderly or patients with DM2. Because DM1 is not only elevated glucose level but first of all a number of hormonal and metabolic abnormalities, the problem of cognitive decline seems to be intricate.

\section{Conclusions}

It seems that even apparent lack of complications is not unambiguous with no cognition decline and women can be more susceptible. DM1 affects children and young patients so explanation of reasons of those abnormalities is very important and needs further investigations.

\section{Acknowledgements}

This study was supported by the grant from Medical University School in Lublin PW 261.

\section{Conflict of interest}

The authors have declared no conflict of interest.

\section{References:}

1. McCrimmon RJ, Ryan CM, Frier BM. Diabetes and cognitive dysfunction. Lancet 2012; 379: 2291-2299.

2. Prasad S, Sajja RK, Naik P, Cucullo L. Diabetes Mellitus and Blood-Brain Barrier Dysfunction: An Overview. J Pharmacovigil 2014; 2: 125.

3. Chmiel-Perzyńska I, Perzyński A, Urbańska EM. Experimental diabetes mellitus type 1 increases hippocampal content of kynurenic acid in rats. Pharmacol Rep. 2014; 66: 1134-1139.
4. Murray AM, Barzilay JI, Lovato JF et al. Action to Control Cardiovascular Risk in Diabetes Memory in Diabetes (ACCORD-MIND) Biomarkers of renal function and cognitive impairment in patients with diabetes. Diabetes Care 2011; 34: 1827-1832.

5. Hugenschmidt CE, Lovato JF, Ambrosius WT et al. The crosssectional and longitudinal associations of diabetic retinopathy with cognitive function and brain MRI findings: the Action to Control Cardiovascular Risk in Diabetes (ACCORD) trial. Diabetes Care 2014; 37: 3244-3252.

6. Cato MA, Mauras N, Ambrosino J et al. Diabetes Research in Children Network (DirecNet). Cognitive functioning in young children with type 1 diabetes. J Int Neuropsychol Soc 2014; 20: 238-247.

7. Tonoli C, Heyman E, Roelands B et al. Type 1 diabetes-associated cognitive decline: a meta-analysis and update of the current literature. J Diabetes 2014; 6: 499-513.

8. Verdelho A, Madureira S, Ferro JM et al. LADIS Study. Differential impact of cerebral white matter changes, diabetes, hypertension and stroke on cognitive performance among non-disabled elderly. The LADIS study. J Neurol Neurosurg Psychiatry 2007; 78: 1325-1330.

9. Tolu-Kendir O, Kiriş N, Temiz F et al. Relationship between metabolic control and neurocognitive functions in children diagnosed with type I diabetes mellitus before and after 5 years of age. Turk J Pediatr 2012; 54: 352-361.

10. McGuinness B, Craig D, Bullock R, Passmore P. Statins for the prevention of dementia. Cochrane Database Syst Rev 2009; 2: CD003160.

\section{Correspondence address}

Adam Perzyński, M.D., Ph.D.

II Department of Psychiatry and Psychiatry Rehabilitation,

Medical University in Lublin

ul. Głuska 2, 20-439 Lublin

Tel. (+48) 81-744-09-67

Fax. (+48) 81-745-33-92

e-mail: adamperzynski@wp.pl

Otrzymano: 04.11.2016

Zrecenzowano: 06.12.2016, 10.12.2016

Przyjęto do druku: 16.12.2016 